〈論文〉

\title{
余剩活性污泥の嫌気性消化に及ぼす前熱処理および滞留時間の影響
}

李王友*野池達也*

\section{The Effect of Thermal Pretreatment and Retention Time on the Degradation of Waste Activated Sludge in Anaerobic Digestion}

\author{
Yuyou $\mathrm{LI}^{*}$ and Tatsuya NOIKE* \\ * Department of Civil Engineering, Tohoku University, Aoba, Sendai 980 Japan
}

\begin{abstract}
The effect of thermal pretreatment on the characteristics of degradation of waste activated sludge in anaerobic digestion was investigated using laboratory-scale batch and continuous experiments at $35 \pm 1^{\circ} \mathrm{C}$. The pretreatment temperature of waste activated sludge ranged from 62 to $175^{\circ} \mathrm{C}$ and the holding time were $15,30,60$ and 90 minutes.

organic solids were solubilizated to soluble proteins and carbohydrates or converted into lower molecular weight compounds such as volatile fatty acid by the thermal pretreatment. The anaerobic biodegradability and methane gas production was increased, and the retention time necessary for anaerobic digestion was possible to be reduced by lower than 10 days. The optimum pretreatment temperature and holding time for the upgrading of anaerobic digestion of waste activated sludge were $170^{\circ} \mathrm{C}$ and 60 minutes respectively. In this pretreament codition, at the retention time from 5.0 to 10.0 days, COD removal efficencies was about $60 \%$ and gas production ranged from 223 to $235 \mathrm{~m} l \cdot \mathrm{gCOD}^{-1}$, which was about 2 times that of the control. The rate of increase in solubilization and anaerobic degradation of major organic compounds in waste activated sludge with thermal pretreatment decreased in the following order: carbohydrate $>$ protein $>$ lipid. The number of total methanogenic bacteria existing at retention time from 1.5 to 10.0 days ranged from $10^{7}$ to $10^{8} \mathrm{MPN}$ per $\mathrm{m} l$ of digester content.
\end{abstract}

Key words : anaerobic digestion, thermal pretreatment, waste activated sludge, biodegradation, methane production

\section{1. 緒論}

嫌気性消化法は有機物を最終的にメタン抢よび $\mathrm{CO}_{2}$ に分解するプロセスであり, 古くから下水污泥・し 尿などの有機廃棄物の有効な処理法またはガスエネル ギー生産法として応用されてきた。本法は省資源・創 エネルギーの利点を有する反面, 下水污泥に対する処 理時間が長く, 分解率が低いなどの欠点が指摘されて いる。污泥の嫌気性消化の効率化を図るために, 有機
物分解率の向上，消化ガス生産量の増大および消化日 数の短縮が強く求められている。

従来, 嫌気性消化の律速段階はメタン生成段階であ るとされ，メタン生成相の浄化機能向上に関して多く の研究が行わ机てきた。しかし，近年盛んに行われる 上らになった二相消化の基磯的研究より，嫌気性消化 の律速段階は基質によって異なることが明らかにされ

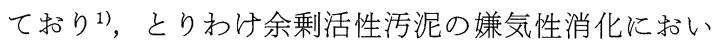
て有機物の分解率が低く，乙か子加水分解段階はプロ

* 東北大学工学部土木工学科, $\bar{\top} 980$ 仙台市荒巻字青葉 
セス全体の律速段階であることが明確に認識されるよ らになった ${ }^{2), 3)}$ 。従って，加水分解反応に和ける基質分 解の促進についての検討を十分に行ら必要があると思 われる。

下水污泥扣よびゴミなどの嫌気性消化の前処理技術 として, 熱処理, 超音波処理, 酸执よびアルカリ処理 などが挙げられる(4) 8)が，その中で熱処理法は下水污 泥脱水性を改善する処理法として開発され，また応用 されてきた7) 10)ので，技術的に簡易であることからそ の適用性が高いと考えられている。熱処理することに より余唾活性洉泥の脱水性が著しく改善される反面, 脱離液の処理の問題が残る欠点を改善するために, Haug ら 11) 13) は熱処理した污泥を消化し, それから脱 水する TP/AD (Thermal Pretreatment/Anaerobic Digestion) プロセスを提案し, 室内抌よびパイロット プラント実験より，その有効性を実証している。Stuckey (4) $^{14}$ 熱処理した余利污泥の生物分解性に着目し て, 150 $275^{\circ} \mathrm{C}$ で熱処理した污泥について嫌気性消化 を行い, 余剰污泥の分解性を増大させる最適温度は $175^{\circ} \mathrm{C}$ であることを報告して扬り，佐藤ら ${ }^{5}$ は余剰污泥

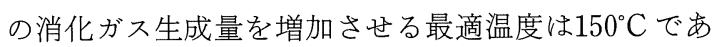
ることを報告している。また平岡ら ${ }^{15)}$ は $60^{\circ} \mathrm{C}$ の低温熱 処理による消化ガス発生量の増大効果を実証し, 低温 熱変性メタン発酵プロセスを提唱している。しかしな がら, これらの研究では熱処理の有用性あるいは最適 温度に関する議論が多いものの, 熱処理した污泥の嫌 気性消化に打ける物質分解の挙動, とりわ滞留時間 の影響を詳細に調べる研究は少なく，嫌気性消化は10 日以上の滞留時間で行われてきたことが多い。

これに対して, 本研究では余唾污泥の嫌気的分解特 性に及ぼす熱処理の促進効果の解明和よび TP/AD プロセスの最適化を目的にして, 回分実験により污泥

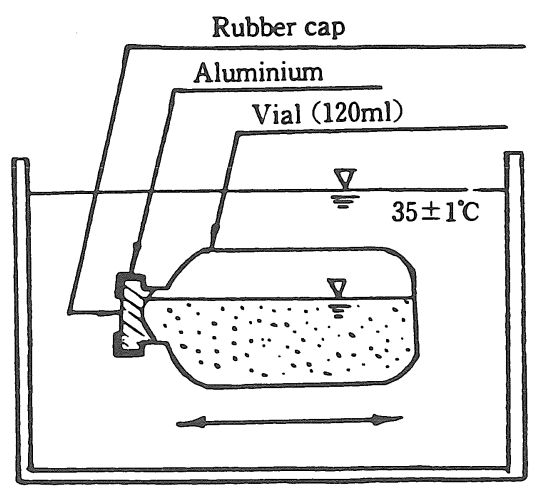

Reciorocal shaker

(Reciprocation : $3.5 \times 120$ strokes $/ \mathrm{min}$ )

Fig. 1 Experimental apparatus for the batch test
の可溶化和よびガス生成量の増加に対する熱処理時間 と温度の影響を明らかにし，また $120^{\circ} \mathrm{C} \sim 175^{\circ} \mathrm{C} て ゙$ 熱処 理した污泥を用いて嫌気性消化の連続実験を行い, 各 種污泥の物質分解過程に及ぼす滞留時間の影響を検討 した。さらに, メタン菌の分布と有機物の分解状況に 関する知見に基づいて, 従来の污泥消化プロセスを, 熱処理により酸生成反応の促進が期待できる酸生成相 と滞留時間の短いメタン生成相から構成される二相プ ロセスに改良する可能性について考察した。

\section{2. 実験材料および方法}

\section{1 熱処理}

$100^{\circ} \mathrm{C}$ 以下の熱処理は恒温水槽で行い, $100^{\circ} \mathrm{C}$ 以上の 熱処理はオートクレーブを用いて行った。各熱処理温 度に対して所定の温度に達した後の維持時間を熱処理 時間とした。

\section{2 嫌気性消化の基質および種污泥}

本研究に用いた余剒活性污泥は $M$ 下水処理場より 採取したものであり，それを濃縮した後，熱処理して 嫌気性消化の基質とした。下水污泥消化槽より採取し た消化污泥に熱処理した污泥を投入して, $35^{\circ} \mathrm{C} て ゙ 2$ 力 月以上馴養されたものを種污泥として用いた。

\section{3 嫌気性消化の実験装置および方法}

\subsection{1 回分実験}

実験装置はFig.1 に示した容積 $120 \mathrm{~m} l$ のバイアル 瓶を用いた。バイアル瓶に熱処理した余唾活性污泥と 種污泥をそれぞれ $40 \mathrm{~m} l$ ずつ注入し，気相部を $\mathrm{N}_{2}$ $(65 \%)+\mathrm{CO}_{2}(35 \%)$ の混合ガスで換気した後, $35^{\circ} \mathrm{C}$ の 恒温振動培養器に入れて実験を開始した。実験期間中,

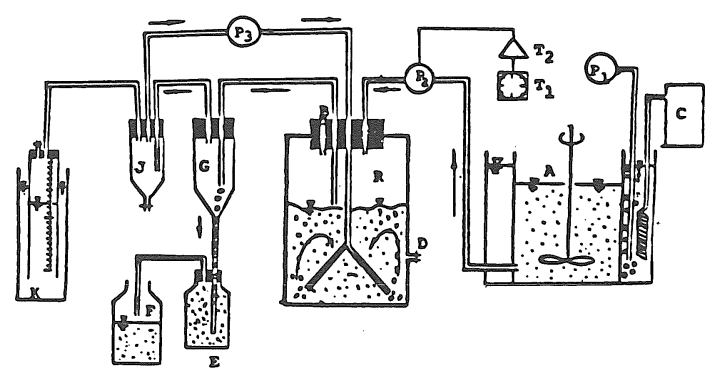

$C_{8} P_{1}:$ Cool dip system

A: Substrate tank

$\mathrm{T}_{1}, \mathrm{~T}_{2}$ : Time control system

$\mathrm{P}_{2}$ : Feed pump

$\mathrm{R}$ : Reactor

$D$ : Mixed liquor sampling port

$B$ : Gas samoling port

$G, E, F$ : Mixed liquor overflow system

$\mathrm{J}, \mathrm{K}$ : Gas collection system

$\mathrm{P}_{3}$ : Gas recirculation pump

Fig. 2 Continuous experimental apparatus 
ガス生成量，ガス組成について測定した。ガス生成量 はブチルゴム栓に注射器を差し込むことによって計量 した後，ガス成分の分析を行った。

\subsection{2 連続実験}

本研究に扔いて用いた実験装置の概略はFig. 2 に 示したように，発生した消化ガスを循環させることに よって反応槽内を攪拌混合し，連続的に基質の投入々 消化液の引き抜きを行ら嫌気性ケモスタット型反応槽 であり，また温度をコントロールするために，反応槽 とガス捕集装置を $35 \pm 1{ }^{\circ} \mathrm{C}$ の大型恒温槽に設置した。 有効容積2.0 3.6l の反応槽を 5 基用意し, 滞留時間 をそれぞれ0.5日，1.5日，3.0日，5.0日抢よび10.0日 と設定した。基質投入ポンプの目づまりを防ぐため に，基質の投入は滞留時間に応じて 1 日 4 ～20回， 1 回60秒間のタイマコントロールシステムを用いて行っ た。生成した消化ガスは酸性飽和食塩水による水上置 換法によって捕集した。

熱処理の温度の違いによって，供試污泥をRun 1 (Control), Run $2\left(120^{\circ} \mathrm{C}\right)$, Run $3\left(150^{\circ} \mathrm{C}\right)$, Run $4\left(170^{\circ} \mathrm{C}\right)$ 特よびRun $5\left(175^{\circ} \mathrm{C}\right)$ の 5 種類に分けて連続実験を 行った。各Runで用いた污泥の化学性状は Table 1 に 示す通りである。各 Run の実験に対して定常状態に達 したことを確認するために，ガス生成量，ガス組成， VFA 濃度㧠よびCOD 濃度などに関して， 1 週間 1 ～ 2 回の測定を行い, 定常状態に打ける $3 \sim 5$ 回の実 験データを平均して, 各実験条件での代表值として採 用した。

Table 1 The chemical composition of thermal pretreated waste activated sludge at different conditions (using for continuous experiment)

\begin{tabular}{|c|c|c|c|c|c|}
\hline $\begin{array}{c}\text { Sludge sample } \\
\text { Sampling time (month) } \\
\text { Thermal pretreatment } \\
\text { Temperature }\left({ }^{\circ} \mathrm{C}\right) \\
\text { Time (min) }\end{array}$ & $\begin{array}{c}\text { Run } 1 \\
\text { Feb. } \sim \text { Apr. } \\
\text { Control }\end{array}$ & $\begin{array}{c}\text { Run2 } \\
\text { Jul• } \sim \text { Aug. } \\
\\
120 \\
30\end{array}$ & $\begin{array}{c}\text { Run3 } \\
\text { Oct. } \sim \text { Nov. } \\
\\
150 \\
30\end{array}$ & $\begin{array}{c}\text { Run4 } \\
\text { Dec. Jan. } \\
170 \\
60\end{array}$ & $\begin{array}{c}\text { Run5 } \\
\text { Feb. } \sim \text { Apr } \\
\\
175 \\
30\end{array}$ \\
\hline $\mathrm{PH}$ & 7.50 & 7.25 & 7.43 & 7.35 & 7.17 \\
\hline $\operatorname{VSS}\left(\mathrm{mg} \cdot l^{-1}\right)$ & 9580 & 4770 & 6100 & 4950 & 4760 \\
\hline VSS/SS (\%) & 82.0 & 76.3 & 77.4 & 76.3 & 76.5 \\
\hline Total $\mathrm{COD}_{\mathrm{cr}}\left(\mathrm{mg} \cdot l^{-1}\right)$ & 15090 & 13030 & 15040 & 15960 & 15930 \\
\hline Solubilization ratio(\%) ${ }^{a}$ & 7.9 & 43.7 & 41.0 & 49.7 & 55.2 \\
\hline T-Protein $\left(\mathrm{mg} \cdot l^{-1}\right)$ & 5880 & 5930 & 5570 & 5570 & 5520 \\
\hline Solubilization ratio(\% $)^{a)}$ & 4.8 & 34.4 & 41.9 & 44.3 & 48.0 \\
\hline $\mathrm{T}$-Carbohytrate $\left(\mathrm{mg} \cdot \mathrm{l}^{-1}\right)$ & 713 & 866 & 917 & 713 & 823 \\
\hline Solubilization ratio(\%) ${ }^{a)}$ & 6.0 & 41.8 & 48.4 & 46.6 & 50.8 \\
\hline T-Lipid $\left(m g \cdot l^{-1}\right)$ & 738 & 685 & 862 & 1080 & 1492 \\
\hline Solubilization ratio(\%) & 16.6 & 30.3 & 28.7 & 38.2 & 30.1 \\
\hline $\begin{array}{l}\text { VFA concentration } \\
\left(\mathrm{mg} \cdot \mathrm{l}^{-1} \text { as COD) }\right.\end{array}$ & 166 & 1120 & 1233 & 2058 & 1912 \\
\hline
\end{tabular}

a) Solubilization ratio $=\frac{\text { Soluble concentration }}{\text { Total }}$

\section{4 メタン菌の計数}

定常状態に招けるTotal メタン菌の計数は 5 本シ リーズの MPN 法を用いて行った。嫌気的操作法は Hungateのガス噴射法を用い，噴射ガスは $350^{\circ} \mathrm{C} て ゙$ 還 元銅カラムによって還元された $\mathrm{CO}_{2}$ ガスを用い

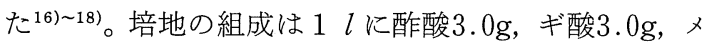
タノール $3.0 \mathrm{~m} l, \mathrm{KH}_{2} \mathrm{PO}_{4} 0.4 \mathrm{~g}, \mathrm{~K}_{2} \mathrm{HPO}_{4} 0.4 \mathrm{~g}, \mathrm{NH}_{4}$ $\mathrm{C} 11.0 \mathrm{~g}, \mathrm{MgCl}_{2} 0.1 \mathrm{~g}$, 微量無機元素 $10 \mathrm{~m} l^{19)}$, ビタミ ン溶液 $10 \mathrm{~m} l^{17)}$, 消化槽の上澄液 $150 \mathrm{~m} l$, 酵母ェキス 2.0 $\mathrm{g}, \mathrm{NaHCO}_{3} 6.0 \mathrm{~g}$, システイン・HCl・ $\mathrm{H}_{2} \mathrm{O} 0.5 \mathrm{~g}, \mathrm{Na}_{2}$ $\mathrm{S} ・ 9 \mathrm{H}_{2} \mathrm{O} 0.5 \mathrm{~g}$, レザズリン $0.002 \mathrm{~g}$ を含有し, 最終 $\mathrm{pH}$

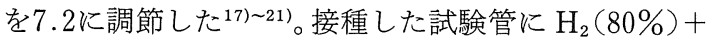
$\mathrm{CO}_{2}(20 \%)$ )混合ガスを 2 気压で注入した後, $36 \pm 1{ }^{\circ} \mathrm{C}$ のふ卵器に招いて 4 週間培養した。メタン菌増殖の陽 性あるいは陰性の判定はガスクロを用いてメタンガス 生成をチェックすることによって行った。

\section{5 分析方法}

ガス組成 $\left(\mathrm{N}_{2}, \mathrm{CH}_{4}, \mathrm{CO}_{2}\right)$ はガスクロマトグラフ 法により分析し，水質項目の測定值は混合液を 3500 rpm で15分間遠心分離して，その上澄液について分析 したものである。な拈，pH， SS，VSS 和よび COD(重 クロム酸法) は下水試験法 ${ }^{22}$, 炭水化物はアンスロン -硫酸法 ${ }^{23)}$, タンパク質は Lowry 法 ${ }^{24)}$, 脂質は BlighDxer 変法 ${ }^{25)}$, 揮発性脂肪酸 (VFA) は FID ガスクロ マトグラフ法により，それぞれ測定した。

\section{3. 実験 結 果}

\section{1 污泥の可溶化に対する熱処理の効果}

余剰活性污泥は主として微生物によって構成されて いるので，熱処理することにより，菌体の死隇掞よび 細胞の破裂に伴い, 細胞の内容物が溶出することが考 えられる。熱処理の操作因子として処理時間と温度と の 2 つがあるが，温度一定の場合，熱処理時間を15分 以上としても可溶化率はわずかしか増えないことが従 来の研究より明らかにされている26),27)。そこで，本研 究では熱処理時間を 30 分間に設定し， $62^{\circ} \mathrm{C}$ から $170^{\circ} \mathrm{C}$ までの温度範囲について可溶化率に及ぼす温度の影響 を調べてみた結果, Fig。3 に示したように, VSの可溶 化率（全有機物に対する溶解性有機物の比率）は掠掠 むね熱処理温度の上昇に伴って増加するが， $100^{\circ} \mathrm{C}$ 前 後では若干低下する現象が見られた。その原因を究明 するために，污泥の主成分であるタンパク質，炭水化

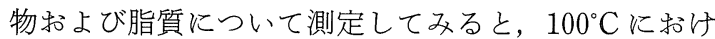
るタンパク質の可溶化率は $80^{\circ} \mathrm{C}$ の場合よりも若干低 くなっていることが分かった。このことは卵の熱によ る固形化現象と関連して考旮れば， $100^{\circ} \mathrm{C}$ 以下の熱処 理に拈いて細胞の破裂に伴うタンパク質の溶出を生じ 


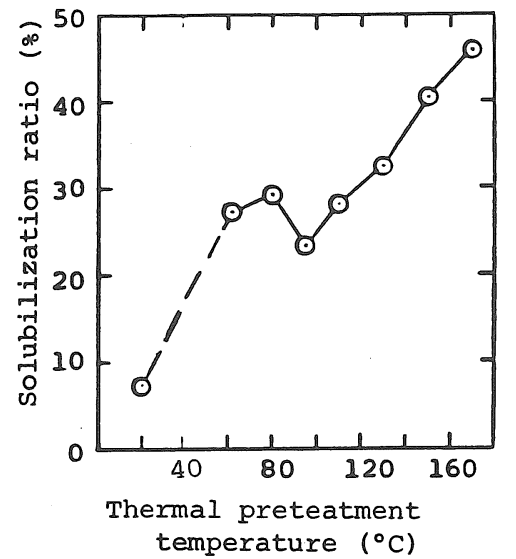

Fig. 3 Effect of thermal pretreatment temperature on solubilization ratio of VS (pretreated for 30 minutes)

ると同時にタンパク質の一部が凝固反応によって固体 になっていることが推察される。タンパク質は余剰活 性污泥 VSS の50～60\%を占めているので，その熱変 性機構は活性污泥の可溶化過程を左右するものと考克 られる。

Table 1 は熱処理による污泥性状の変化を示してい る。これによれば, タンパク質と炭水化物の可溶化率 は熱処理温度の上昇とともに増加している。また, 夕 ンパク質, 炭水化物抒よび脂質の 3 つの成分について 比較すると, 同じ温度に和ける可溶化率は炭水化物> タンパク質＞脂質の順になって打り，熱処理による可 液化効果は成分によって異なることが分かる。

\section{2 回分実験に上る検討}

污泥の消化ガス生成量を調べるために，30日間の回
分実験を行い, 30 日間で投入した污泥 $1 \mathrm{gVS}$ 当たりの ガス生成量を供試污泥のガス生成能とした。Fig.4 は ガス生成能に及ぼす熱処理時間掞よび温度の影響を示 している。これによれば, 熱処理温度を一定にした場 合, 処理時間が長ければ長いほどガス生成量が若干増 党る(特に, $150^{\circ} \mathrm{C}$ の高温域ではこの傾向が著しい)が, 30分間以上になると, メタンガス生成量の増加は少な かった。また，熱処理時間を30分間に一定にして温度 を変える場合では，消化ガスの生成量は扮括むね処理 温度の上昇に伴って増兄るものの，メタンガスの増加 率で見ると， $150^{\circ} \mathrm{C} て ゙ 30 \%$ 程度と最大值となっている のに対して, $62^{\circ} \mathrm{C}$ の低温域熱処理においても $12 \%$ 程度 の増加が見られる。しかし, $100^{\circ} \mathrm{C}$ で熱処理した場合, メタンガスの増加率は $80^{\circ} \mathrm{C}$ の場合と比べれば若干低 くなっている。このことはFig. 3 の可溶化率と関連し て和り, $100^{\circ} \mathrm{C}$ 前後でタンパク質の可溶化率が低下し たことによるものと考光られる。

上記の結果より，余䛢污泥の可溶化扣よび消化ガス 生成量の増加に対する熱処理の促進効果は $100^{\circ} \mathrm{C}$ 前後 を境界にして低温域と高温域に分けて考它られる。平 岡ら ${ }^{15)}$ とょって報告されたように, $60^{\circ} \mathrm{C} \sim 80^{\circ} \mathrm{C}$ の低温 域に括いて子熱処理の効果は十分認められるが，高温 域と比較すればその効果は著しく少ないので，本研究 に打いては $120^{\circ} \mathrm{C} \sim 175^{\circ} \mathrm{C}$ の高温域熱処理污泥につい て1.5日，3.0日，5.0日和よび10.0日の滞留時間で連続 実験を行い，污泥の嫌気性分解特性に及ぼす熱処理温 度抢よび消化時間の影響を考察した。

\section{3 連続実験における物質の分解過程}

\subsubsection{COD の除去率}

Fig. 5 は COD 除去率に及ぼす熱処理の促進効果を 示している。これによると，熱処理することによって
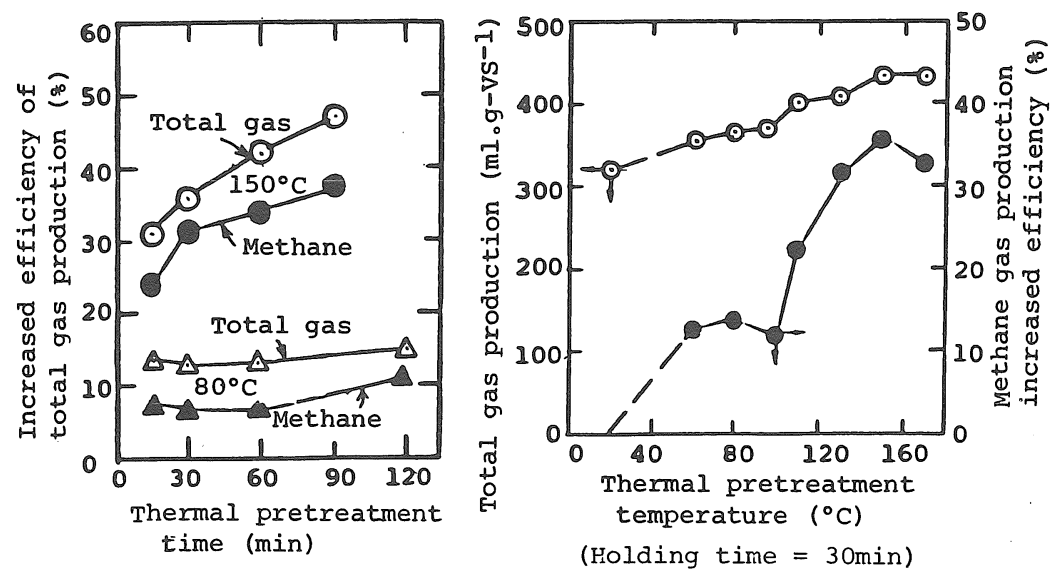

Fig. 4 Effect of thermal pretreatment on gas production in anaerobic digestion (by batch experiments of 30 days) 


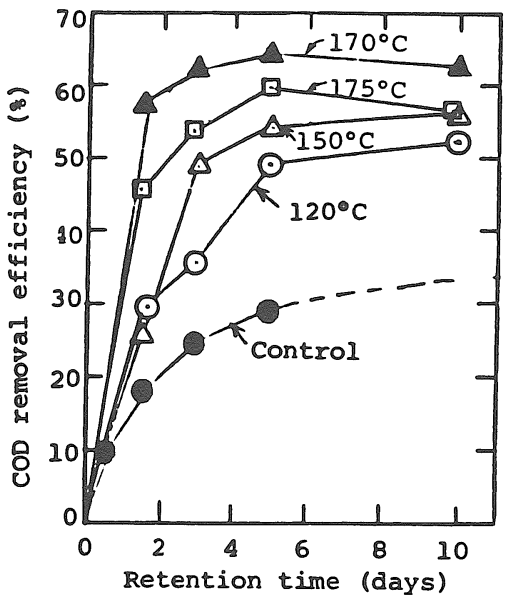

Fig. 5 Effect of thermal pretreatment temperature on COD removal efficiency at different retention time. $(\mathbf{\Delta})$ pretreated at $170^{\circ} \mathrm{C}$ for minutes $(\bigcirc)$ $(\triangle)(\square)$ pretreated for 30 minutes

余剰活性污泥の COD 除去率が大幅に向上されたこと が分かる。例党ば，滞留時間 5 日の条件に损いて， $120^{\circ} \mathrm{C}$, $150^{\circ} \mathrm{C}, 170^{\circ} \mathrm{C}$ 打よび $175^{\circ} \mathrm{C}$ で熱処理した污泥の COD 除去率はそれぞれ $49.7 \%, 54.9 \%, 64.3 \%$ 打よび $59.0 \%$ であり，対照系の $28.3 \%$ よそれぞれ $21.4 \%, 26.6 \%$ ， $36.0 \%$ 扝よび $30.7 \%$ ほど上回っている。筆者ら ${ }^{1}$ は回 分実験より100日間の嫌気性消化を通じて活性污泥の COD の $57 \%$ 程度が除去された結果を報告して扣り, 上 記の結果と比較すれば, $150^{\circ} \mathrm{C} \sim 175^{\circ} \mathrm{C}$ で熱処理した余 剰污泥に対しては, 消化時間を 5 日まで短縮しても活 性污泥の 100 日間消化に相当する高いCOD 除去率が 得られることが分かる。

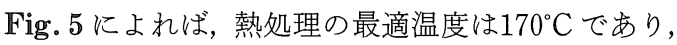
Stuckey ら $^{14)}$ の結果と一致した。COD 除去率に対する 滞留時間の影響については，5 日と10日との間には差

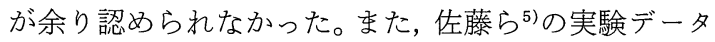
によれば $120^{\circ} \mathrm{C}$ と $150^{\circ} \mathrm{C}$ 熱処理污泥の COD 除去率は 10日と20日の条件でほぼ同じであった。従って，本研 究の結果は熱処理污泥の嫌気性消化に対して滞留時間 が10日以下に短縮できることを裏づけている。

\subsubsection{VSS の分解书よび溶解性 COD の除去}

Table 1 に示したように, 熱処理した污泥に溶解性 有機物の占める割合が大きいので, 物質分解過程を解 析するために, 固形有機物拉よび溶解性有機物を分け て考察する必要がある。

Fig. 6 VVSS の加水分解率に及ぼす熱処理拉よび 消化時間の影響を示している。これによれば, VSS の 分解率に及ぼす熱処理の影響は消化の滞留時間によっ

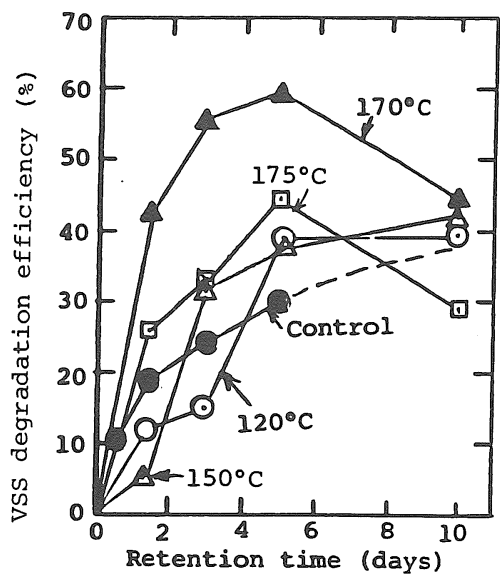

Fig. 6 Effect of thermal pretreatment on VSS degradation in digester at different retention time

て若干異なるが，消化時間 5 日の条件に打いては熱処 理した污泥のVSS 分解率がそれぞれ $120^{\circ} \mathrm{C} の$ 系: $38.5 \%, 150^{\circ} \mathrm{C}$ の系: $38.1 \%, 170^{\circ} \mathrm{C}$ の系: $59.8 \%$ 扔よ び $175^{\circ} \mathrm{C}$ の系： $42.3 \%$ であり, 対照系の $30.8 \%$ より上 回って招り，いずれの熱処理系に抢いてもVSS 分解 率の向上が認められる。各系の VSS 分解率曲線を比 較すれば, 同じ消化時間にお秄る促進効果は $170^{\circ} \mathrm{C} の$ 系が最も大きかった。また，同じ系に打ける消化の滞 留時間の影響を見てみると, $120^{\circ} \mathrm{C}$ と $150^{\circ} \mathrm{C}$ 熱処理の場 合は対照系と同じょうに, VSSの分解率が滞留時間の 増大とともに大きくなるのに対して, $170^{\circ} \mathrm{C}$ と $175^{\circ} \mathrm{C}$ の 系では10日の VSS 分解率が逆に 5 日より若干低く なっている。この結果は高温熱処理した污泥を長い滞 留時間で消化させる場合には, VSS の分解に阻害現象 が起こることを示唆している。

Fig. 7 に溶解性 COD 濃度に及ぼす熱処理および消 化時間の影響を示している。従来, 熱処理した污泥を 直接脱水した場合に高濃度の COD 成分を含有する脱 離液が出てくることが問題となったが，Fig.7 とよれ ば, 各温度条件で熱処理した污泥の溶解性 COD 濃度 は消化時間の増加に伴って低くなり, 滞留時間 5 日以 上の条件に和いては溶解性 COD の濃度が1430 1740 $\mathrm{mg} \cdot l^{-1}$ になり，コントロール系の $1000 \mathrm{mg} ・ l^{-1}$ よりや や高いものの, 大差はなくなった。このことは熱処理 によって生成された溶解性有機物はほとんど分解され たが，一部分が分解しにくい成分に転化されたことを 示唆している。

\subsection{3 ガス生成}

Table 2 はガス生成に及ぼす熱処理抒よび消化時間 の影響を示している。各処理系に揖いて，ガス生成量 
Table 2 Effect of retention time and thermal pretreatment on the gas production rate, gas production and gas composition

\begin{tabular}{|c|c|rrrc|}
\hline \multicolumn{2}{|c|}{ Retention time (Days) } & 1.5 & 3.0 & 5.0 & 10.0 \\
\hline \multirow{3}{*}{ Gas production } & Control & 741 & 386 & 327 & - \\
rate & $120^{\circ} \mathrm{C}$ & 1250 & 660 & 415 & 241 \\
$\left(\mathrm{~m} l \cdot l^{-1} \cdot\right.$ day $\left.^{-1}\right)$ & $150^{\circ} \mathrm{C}$ & 1620 & 909 & 624 & 325 \\
& $170^{\circ} \mathrm{C}$ & 1810 & 1047 & 712 & 376 \\
& $175^{\circ} \mathrm{C}$ & 1725 & 947 & 690 & 339 \\
\hline Gas production & Control & 74 & 77 & 108 & - \\
$\left(\mathrm{m} l \cdot \mathrm{g}^{-1} \mathrm{COD}\right)$ & $120^{\circ} \mathrm{C}$ & 144 & 152 & 159 & 185 \\
& $150^{\circ} \mathrm{C}$ & 163 & 181 & 208 & 216 \\
& $170^{\circ} \mathrm{C}$ & 170 & 197 & 223 & 235 \\
& $175^{\circ} \mathrm{C}$ & 162 & 171 & 216 & 212 \\
\hline Percent & $\mathrm{Control}$ & 70.3 & 69.1 & 69.4 & - \\
methane & $120^{\circ} \mathrm{C}$ & 73.0 & 71.0 & 72.4 & 72.6 \\
$(\%)$ & $150^{\circ} \mathrm{C}$ & 70.6 & 69.2 & 69.4 & 69.2 \\
& $170^{\circ} \mathrm{C}$ & 69.5 & 69.6 & 69.1 & 70.0 \\
& $175^{\circ} \mathrm{C}$ & 71.5 & 71.9 & 72.3 & 72.0 \\
\hline
\end{tabular}

は滞留時間の増大に伴って増えるが, $150 \sim 175^{\circ} \mathrm{C}$ の系 では 5 日と10日の間に大差がなかった。また，同じ滞 留時間に扣ける各系のガス生成量を比較すると, 熱処 理することによって，投入污泥 $1 \mathrm{~g}$ COD 当たりの生成 量が著しく増大されることが分かる。例えば，滞留時 間 5 日の条件に和いて, 対照系の $108 \mathrm{~m} l \cdot \mathrm{g}^{-1} \mathrm{COD}$ に対 して, 熱処理した系では159 $223 \mathrm{~m} l \cdot \mathrm{g}^{-1} \mathrm{COD}$ であり, ガス生成量の増加率は $120^{\circ} \mathrm{C}$ の系で $47 \%, 150^{\circ} \mathrm{C}$ の系で $93 \%, 170^{\circ} \mathrm{C}$ の系で $106 \%, 175^{\circ} \mathrm{C}$ の系で $100 \%$ であって, $150 \sim 175^{\circ} \mathrm{C}$ で30分間熱処理したことにより，ガス生成 量が倍増されている。消化ガス中のメタン含有率はい ずれの条件に扣いても70\%程度に安定して打り，熱処 理による顕著な変化はなかった。

本研究の実験条件においてガス生成速度は滞留時間 の増大に伴って少なくなり，5日に扣けるガス生成速 度は持よそ10日の条件の 2 倍であった。この結果を Fig.5に拈けるCOD 除去率と関連して考察すると, 両条件での COD 除去率が注ぼ同じであったため, ガ ス生成速度は主として有機物の投入負荷によって支配 されたものと考觉られる。

\subsection{4 メタン菌の計数}

前述した結果より短い滞留時間に扣いてもメタン発 酵が順調に進んでいることが推察される。一方, 滞留 時間が短くなるとメタン菌の洗い出しが生じるため, 十分なメタン菌を保有することができないといわれて いる。本研究ではメタン菌の分布を明らかにするため に, MPN 法を用いてトータルメタン菌の生菌数を測 定した。

Table 3 にトータルメタン菌の計数結果を示してい

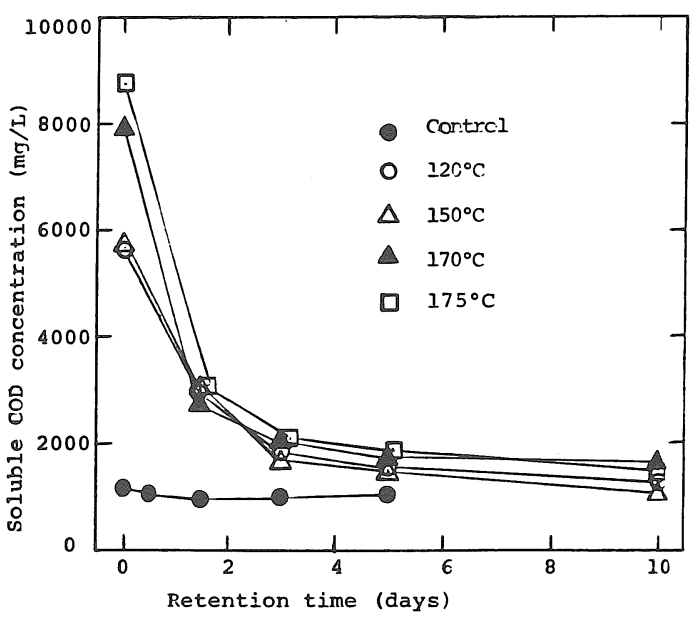

Fig. 7 Effect of retention time and thermal pretreatment on soluble COD concentration of digester effluent

る。メタン菌の生菌数は $1.6 \times 10^{7} \sim 3.5 \times 10^{8} \mathrm{No}^{\circ} \mathrm{m} l^{-1}$ あるいは $5.4 \times 10^{9} \sim 1.8 \times 10^{11} \mathrm{No}^{\circ} \mathrm{g}^{-1} \mathrm{VSS}$ であった。 一方，Zeikus ${ }^{28)}$ は污泥消化槽に打けるメタン菌の数が $10^{6} \sim 10^{8} \mathrm{No}^{\circ} \mathrm{m}^{-1}$ と報告し, Mackie and Bryant ${ }^{21)}$ は 帯留時間10日の畜産廃棄物の消化槽に扣いて $2.1 \times 10^{8}$ $\mathrm{No} \cdot \mathrm{m} l^{-1}$ のメタン菌が生存していると報告して和り, 本研究の結果と一致するものである。また, 3.0 日の短 い滞留時間に打いても, $10^{8} \mathrm{No}^{\circ} \mathrm{m} l^{-1}$ のメタン菌が検出 されたことから, 滞留時間が 3 日以上になればメタン 菌は十分増殖できることが分かる。

\section{3 .5 污泥の各成分の分解}

污泥の各成分の分解特性に及ぼす熱処理の影響を明 らかにするために，Fig.8に嫌気性消化に执けるタン パク質，炭水化物和よび脂質の分解率を示した。タン パク質执よび炭水化物に対する熱処理の促進効果がい ずれの条件でも大きいのに対して，脂質に対する促進 効果は $120^{\circ} \mathrm{C}$ 打よび $150^{\circ} \mathrm{C}$ の系では認められなかった。 また, Fig.8に示したよらに, 対照系に拈いて各成分の 分解率は脂質>タンパク質>炭水化物の順になってお り，炭水化物は最も分解されにくいが，熱処理による 促進効果は炭水化物に対して最も顕著であった。通常, 炭水化物が分解されやすいといわれているが，活性污 泥に含まれた炭水化物は大部分が細胞壁の構成成分と して強固な構造になっているため, 嫌気性細菌に分解 されにくいと考觉られる。Table 1 に示された通り, 熱 処理による炭水化物の可溶化率が高く, また溶解性糖 類が嫌気性消化で $100 \mathrm{mg} \cdot l^{-1}$ 以下の低い濃度まで分解 されたので，結果として炭水化物の分解率は大幅に向 上した。これに対して，熱処理によってタンパク質の 
Table 3 MPN values of methanogenic bacteria in different conditions

\begin{tabular}{|c|crrc|}
\hline RT (Days) & 1.5 & 3.0 & 5.0 & 10.0 \\
\hline & \multicolumn{4}{|c|}{$\times 10^{6} \mathrm{No} \cdot \mathrm{m}^{-1}$} \\
$170^{\circ} \mathrm{C}$ & - & 300 & 350 & - \\
$175^{\circ} \mathrm{C}$ & 19 & 94 & 230 & 410 \\
\hline & \multicolumn{4}{c}{$\times 10^{9} \mathrm{No}^{\circ} \mathrm{g}^{-1} \mathrm{VSS}$} \\
$170^{\circ} \mathrm{C}$ & - & 138.0 & 176.0 & - \\
$175^{\circ} \mathrm{C}$ & 5.4 & 28.4 & 84.6 & 121 \\
\hline
\end{tabular}

Table 4 Convertion factors used in COD material balance

\begin{tabular}{|l|l|}
\hline \multicolumn{1}{|c|}{ Parameter } & \multicolumn{1}{|c|}{ Conversion factor } \\
\hline Carbohydrate & $1.067 \mathrm{mg}-\mathrm{COD} \cdot \mathrm{mg}^{-1}$-glucose \\
Protein & $1.240 \mathrm{mg}-\mathrm{COD} \cdot \mathrm{mg}^{-1}$-protein \\
Lipid & $2.880 \mathrm{mg}-\mathrm{COD} \cdot \mathrm{mg}^{-1}$-lipid \\
Acetic acid & $1.066 \mathrm{mg}-\mathrm{COD} \cdot \mathrm{mg}^{-1}$-acetic acid \\
Propionic acid & $1.512 \mathrm{mg}-\mathrm{COD} \cdot \mathrm{mg}^{-1}$-propionic acid \\
Butyric acid & $1.816 \mathrm{mg}-\mathrm{COD} \cdot \mathrm{mg}^{-1}$-butyric acid \\
Valeric acid & $2.037 \mathrm{mg}-\mathrm{COD} \cdot \mathrm{mg}^{-1}$-valeric acid \\
Methane gas & $2.857 \mathrm{mg}-\mathrm{COD} \cdot \mathrm{ml}^{-1}-\mathrm{CH}_{4}$ \\
\hline
\end{tabular}

分解率が向上されたものの, 残存溶解性タンパク質濃 度も $400 \mathrm{mg} \cdot l^{-1}$ 以上に増えてきた。これは溶解性タン パク質の一部分が難分解性のものに変質したため ${ }^{14)}$ と 思われる。

4. 考察

\section{1 連続実験における物質収支}

嫌気性消化に扝ける物質の分解過程は固形物の加水 分解，酸生成扣よびメタン生成の三段階に分けられる が，各条件での物質転化状況を把握するために，本研
究に扣いては, 有機物をその存在形態によって固形物, 溶解物特よびメタンガスの 3 つの部分に分類し, さら に溶解物に対して SVS (溶解性タンパク質, 炭水化物 および脂質)，VFA (揮発性有機酸) 执よびその他の 3 種類に分けて COD 物質収支を算出して Table 5 に示 した。また，計算に用いた各成分の COD 換算係数は

Table 4 に示した。

全流入 COD に対する流出 COD の回収率（Recovery）は汪とんど $80 \%$ 超光ているものの，100\%に近 い值が少なかった。これは硫酸還元菌の代謝による COD の消費を計算していないことと，投入污泥 COD 濃度の変動に伴ら分析の誤差などによるものと考えら れる。硫酸還元菌の代謝については Zeikus ${ }^{28)}$ は泒泥消 化槽に括いて $10^{4}$ 個・ $\mathrm{m} l^{-1}$ の硫酸還元菌が検出された ことを報告して扣り，この硫酸還元菌は酢酸利用メ夕 ン菌扣よび水素生成性酢酸生成菌との間に基質の競合 関係が存在し，メタンガスの回収率を低下させる29),30) と指摘されてきた。ぬた，本研究に用いた基質は下水 処理場から採取した余剒活泥であったため，できるだ け基質の均一性を保つよら工夫したが，投入基質濃度 和よび反応槽流出水濃度に $10 \%$ 程度の誤差は避けられ なかった。

\section{2 熱処理の促進作用}

メタン発酵に及ぼす熱処理の促進効果を明らかにす るために，熱処理执よび嫌気性消化による物質存在形 態の変化を COD 物質収支で Table 5 に示した。まず, 熱処理だけによる影響に注目してみると，対照系污泥 に拉いて有機物の $92.1 \%$ が固形物であるのに対して， 熱処理污泥には固形物(VSS)の分解に伴い, SVS（溶 解性タンパク質, 炭水化物执よび脂質) と VFA が増え てきて， $175^{\circ} \mathrm{C}$ 系の場合では固形物 $44.8 \%, \mathrm{SVS}$
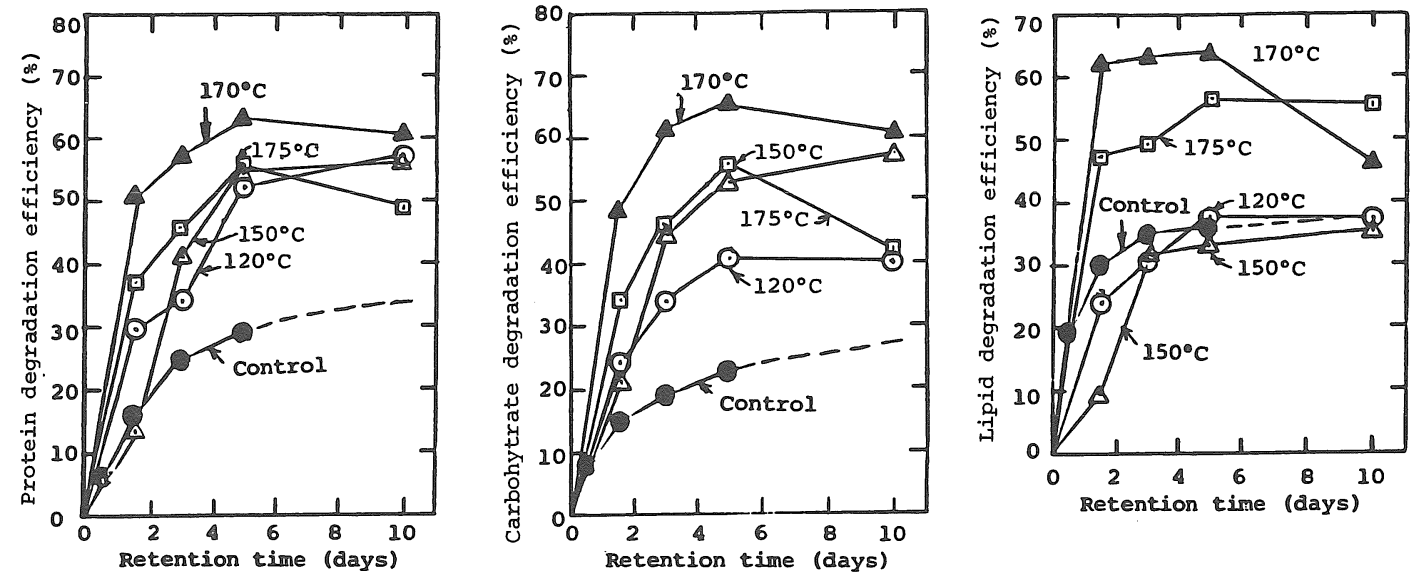

Fig. 8 Effect of thermal pretreatment on anaerobic biodegradation of proteins, carbohytrates and lipids in waste activated sludge 
Table 5 COD material blance (Unit: \%)

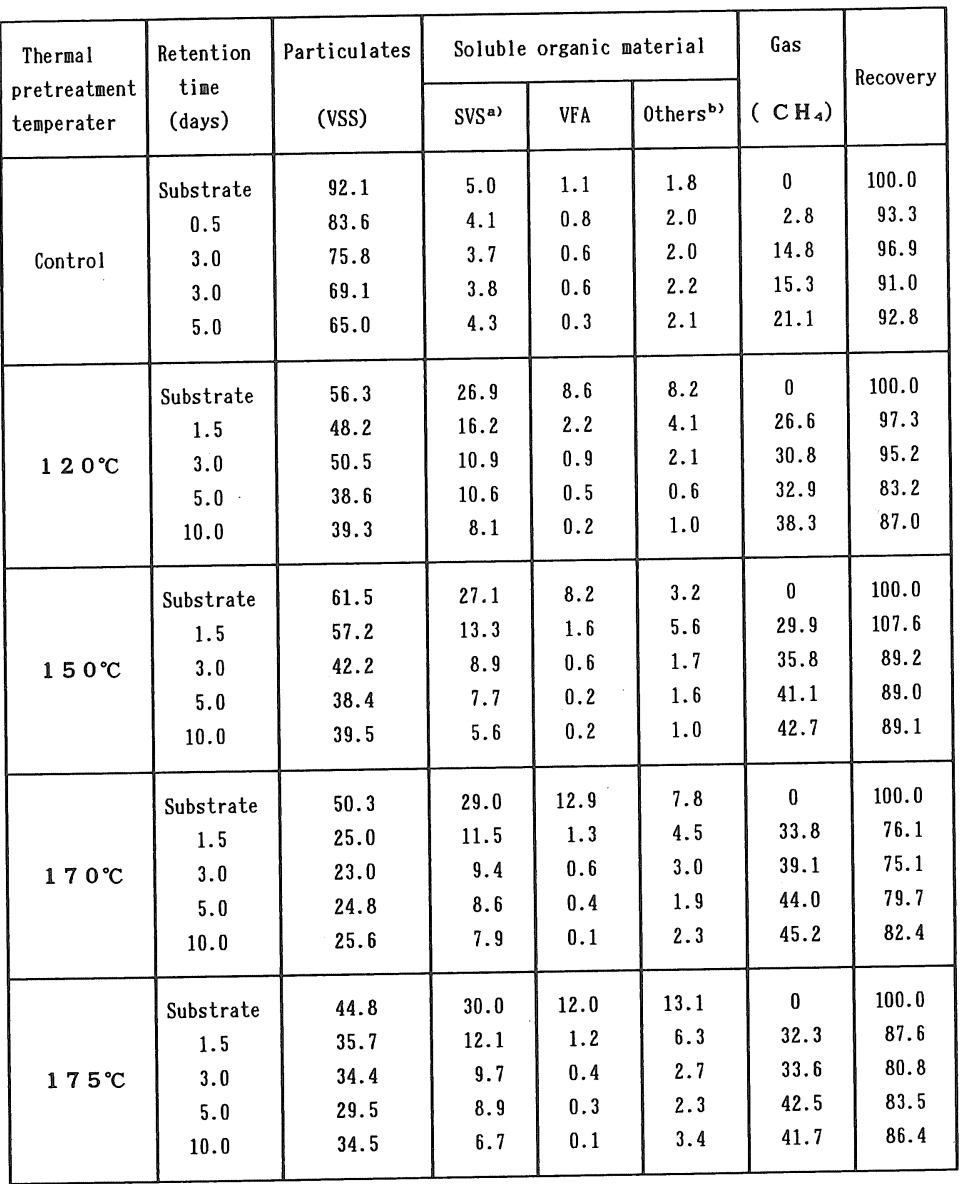

a). SVS = soluble protein + soluble carbohydrate + soluble lipid

b), 0 thers = soluble COD - VFA - SVS

$30.0 \%$, VFA $12.0 \%$ 㧊よびその他（Others 13.1\% になった。このデータは熱処理によって固形有機物が 可溶化されただけでなく，その一部分がさらにVFA 扣よびその他の低分子有機物まで分解されたことを示 唆している。これより，熱処理によって難分解性の固 形物がメタン発酵しやすい物質に変質されることが分 かる。嫌気性消化に扣いては上記の熱処理污泥に含ま れるVSS がさらに分解され， $170^{\circ} \mathrm{C}$ 㧊よび $175^{\circ} \mathrm{C}$ 熱処 理・5 日消化の場合，未分解の VSS はトータル COD の30\%以下になり，対照系に比較してVSSの分解率 は35\%程度向上した。また，加水分解されて生成した 溶解性有機物は滞留時間の増加に伴い，徐々に除去さ れ, 大部分がガス相へ移行する。その結果, 熱処理し た系ではメタンガスの回収率は著しく増加し, 滞留時 間 5 日の条件で比較すると, 対照系の $21.1 \%$ に対して, $120^{\circ} \mathrm{C}, 150^{\circ} \mathrm{C}, 170^{\circ} \mathrm{C}$ および $175^{\circ} \mathrm{C}$ 熱処理の系に扔いて
それぞれ $32.9 \% ， 41.1 \% ， 44.0 \%$ 物よび42.5\%であっ た。このように, 前熱処理は余唾污泥の分解率执よび メタン回収率の向上に対して有効な方法であり，その 促進効果は以下の 3 つの作用によるものと考学られ る。

（1）熱処理に伴う固形有機物の可溶化,

（2）熱処理に伴ら低分子およびVFAなどのメタン 発酵しやすい有機物の生成,

（3）熱変性による固形有機物の嫌気的加水分解率の 向上。

\section{3 最適熱処理条件}

嫌気性消化に及ぼす熱処理時間の影響については, 熱処理による污泥の可溶化反応は30分で注ぼ平衡にな ることとそれ以上熱処理時間を増やしてもガス生成量 の増加が少ないことから，30分で妥当と考学られた。 本研究の回分実験 (Fig。4)によれば，熱処理の時間が 


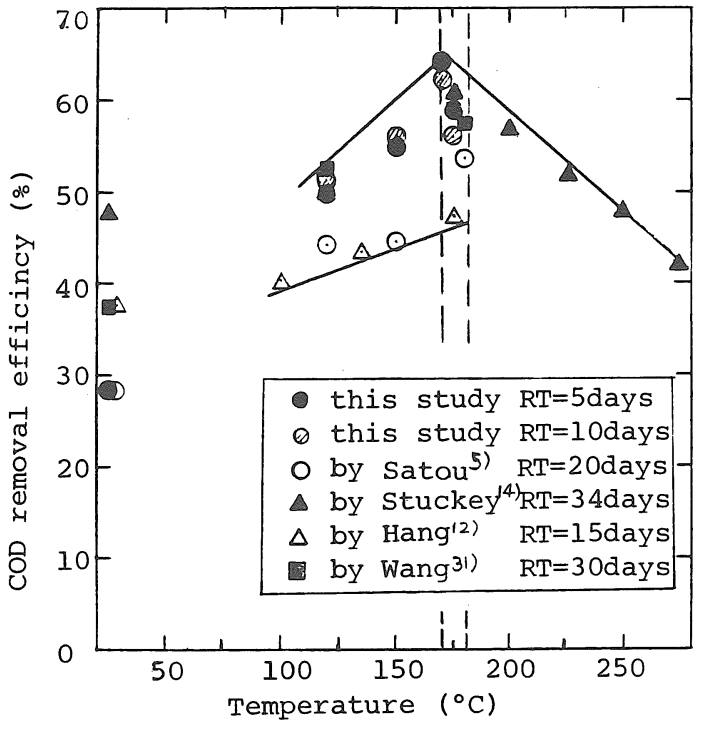

Fig. 9 Optimum thermal pretreatment temperature for increase anaerobic degradation of waste activated sludge by this and another studies

長ければ長いほど，消化ガス生成量の増加率が若干高 くなる傾向が見られる。熱処理温度の影響については 本研究ではまず $62^{\circ} \mathrm{C} \sim 175^{\circ} \mathrm{C}$ の温度範囲にわたる回分 実験（Fig.4）により $150^{\circ} \mathrm{C}$ 前後に最適温度が存在する ことを予想した上で, $120^{\circ} \mathrm{C}, 150^{\circ} \mathrm{C}, 170^{\circ} \mathrm{C}$ 扤よび $175^{\circ} \mathrm{C}$ の条件についてさらに連続実験を加光，嫌気性消化を 促進するための最適熱処理温度を検討した。Fig.5 お よびTable 2 に示したように，有機物分解率揖よびメ タンガス生成量を向上させる最適熱処理温度は $170^{\circ} \mathrm{C}$ であることが分かる。亦た，その他の研究者の結果と 比較するために, 本研究抒よびいままで報告された データをFig. 9 によるめた。これによれば, 各研究者 の用いた污泥抢よび消化時間がそれぞれ異なるため, データのばらつきがあるものの, $170^{\circ} \mathrm{C}$ 前後で有機物 分解率は一番高い点に打いて一致した。

\section{4 傔気性消化における帯留時間の影響}

嫌気性消化の各滞留時間に拈いてVFA が注とんど 蓄積せず投入 COD の $2.2 \%$ 以下 (Table 5) になってい る。これをメタンガスの回収率打よび Table 3 に示し たメタン菌の生菌数と関連してみれば, 生成した VFAが速やかにメタンまで分解されたことが分か る。それゆ光, 熱処理によって可溶化反応が促進され たものの，污泥の主成分がタンパク質と脂質であり， 酸発酵しやすい炭水化物が少ないため, 酸生成段階が 律速段階になっていると思われる。嫌気性消化に和け る污泥の分解率揖よびガス生成に及ぼす滞留時間の影
響についてはFig.5〜8 抒よびTable 2〜3によれば 5 日以下の条件に括いて有機物の分解率とメタン生成 量が滞留時間の増大に伴って増大するが，5 日と10日 の間には余り差が認められなかった。このことは熱処 理污泥に含まれた分解可能性有機物が 5 日の滞留時間 でほとんど分解されたことを示唆している。加光て, COD 除去率が高かったこと, メタン菌の生菌数が多 かったこと、メタン発酔が十分行われたこと，などの 結果から判断して, $150 \sim 175^{\circ} \mathrm{C}$ で熱処理した余剰活性 污泥に対しては消化時間は 10 日以下に短縮することが 可能である。

\section{5. 結 論}

本研究により得られた主な結果抢よび結論は以下の よらにまとめられる。

1 ) 余剰活性污泥の嫌気性消化に及洁す熱処理の促進 効果は顕著であり，そのメカニズムが(1)熱処理に伴う 有機物の可溶化，(2)熱処理に伴うVFA 抒よびその他 のメタン発酵しやすい有機物の生成，(3)熱変性による 固形物の加水分解率の向上の 3 つに文められる。熱 処理の結果，有機物分解率とメタンガスの回収率が向 上されただけでなく，嫌気性消化の滞留時間を 10 日以 下に短縮することが可能である。

2 ）污泥の可溶化率は熱処理温度の上昇に伴って増加 するのに対して，嫌気性消化に打忷る有機物の除去物 よびメタンガス生成に及ぼす熱処理温度の影響につい ては最適温度が存在する。

3) $\mathrm{TP} / \mathrm{AD}$ プロセスの最適運転条件は有機物の除去 率およびガス生成量から判断すれば，熱処理が時間60 分, 温度 $170^{\circ} \mathrm{C}$ でたり, 嫌気性消化時間が5 10日であ る。この条件に招いて COD 除去率招よびガス生成量 はそれぞれ約 $60 \%$ 揖よび223 235 $\mathrm{m} l \cdot \mathrm{g}^{-1} \mathrm{COD}$ であ り，対照系より倍増する。

4) 污泥の嫌気性消化に打けるメタン菌の生菌数は $10^{7} \sim 10^{8} \mathrm{No}^{\circ} \mathrm{m}^{-1}$ あるいは $10^{9} \sim 10^{11} \mathrm{No}^{\circ} \mathrm{g}^{-1} \mathrm{VSS}$ であ り，その分布が滞留時間に影響される。滞留時間が 3 日以上になれば, メタン菌は $10^{8} \mathrm{No} ・ \mathrm{~m} l^{-1}$ をで増殖する ことが可能である。

5) 熱処理した余剩活性污泥の嫌気性消化に扮いて も，基質の大部分がタンパク質と脂質であるため，律 速段階がメタン生成段階ではなく，酸生成相にある。 よって，熱処理した污泥に対してさらに二相分離を行 ら必要はなく, むしろ $\mathrm{TP} / \mathrm{AD}$ プロセスを熱処理によ り酸生成反応の促進が期待できる酸生成相十メタン生 成相之の改良式二相消化プロセスに見直した方が適切 と考光られる。

6 ）熱処理による余剰污泥の各成分の嫌気的分解率の 
向上は可溶化率と同じく，炭水化物>タンパク質>脂 質の順で大さい。

7 ） $\mathrm{TP} / \mathrm{AD}$ プロセスの脱離液の有機物濃度は通常の 消化槽より高くなるが, 滞留時間が 5 日以上になれば, 流入 COD 濃度の $10 \%$ 以下になることが可能である。

謝辞：本研究を行らにあたり，污泥採取の面で御協力 頂いた仙台市下水処理場の皆様に深く謝意を表しま す。また，実験を行らにあたり，御尽力下さった東北 大学工学部土木工学科学生足利伸行君に心から感謝致 します。

（原稿受理 昭和63年10月13日）

\section{引用文 献}

1) Noike, T., Endo, G., Chang, J., Yaguchi, J. and Matsumoto, J. (1985) Characteristics of carbohydrate degradation and the rate-limiting step in anaerobic digestion, Biotechnology and Bioengineering, 27, 1482-1489.

2) 李玉友, 野池達也 (1987) 嫌気性消化の酸生成相に打ける余 剩活性污泥の分解特性，水質污濁研究， 10, 729-740.

3) Eastman, J.A. and Ferguson, J.F. (1981) Solubilization of particulate organic carbon during the acid phase of anaerobic digestion, Journal of water pollution control federation, $53,352-366$.

4 ) 山内徹（1982）下水余剩污泥・嫌気性消化の前処理の研究, 第18回衛生工学研究討論会講演論文集, 18, 184-189.

5 ) 佐藤和明, 舘山祐清 (1982) 熱処理污泥の嫌気性消化に関す る研究, 第18回衛生工学研究討論会講演集, 18, 176-181.

6 ) 清水達雄, 岡村享, 釜沢正実, 那須義和 (1986) 嫌気性消化 による污泥処理の効率化一污泥の可溶化の効果一, 土木学会第 41回年次学術講演会講演集, II-458, 915-916.

7 ) R.B. Brooks, B.Sc., M.Sc., Grad.I.Chem.E. (1968) Heat treatment of activated sludge, Water Pollution Control, 67, 592-601.

$8)$ R.B. Brooks, B.Sc., M.Sc., Grad.I.Chem.E. (1970) Heat treatment of sewage sludge, Water Pollution Control, 69, 92 -99 .

9) Everett, J.G. (1972) Dewatering of wastewater sludge by heat treatment, Journal of Water Pollution Control Federation, 44, 93-100.

10）土木学会（1972）下水污泥の処理・処分抢よび利用に関する 研究報告書.

11) Haug, R.T. (1977) Sludge processing to optimize digestibility and energy production, Journal of Water Pollution Control Federation, 49, 1713-1721.

12) Haug, R.T. (1978) Effect of thermal pretreatmes on digestibility and dewaterability of organic sludge, Journal of Water Pollution Control Federation, 50, 73-85.

13) Haug, R.T., LeBrun, T.J. and Tortorici, L.D. (1983) Thermal pretreatment of sludges- a field demonstration, Journal of Water Pollution Control Federation, 55, 23-24.
14) Stuckey, D.C. and McCarty, P.L. (1984) The effect of thermal pretreatment on the anaerobic biodegradability and toxicity of waste activated sludge, Water Rereach, 18 , 1343-1353.

15) 平岡正勝, 武田信生, 酒井伸一, 北井克彦, 小林信博 (1986) 熱変性メタン発酵システムのパイロットプラント研究, 下水道 協会誌, 264, 38-49.

16) 日本細菌学会教育委員会編 (1982) 嫌気性菌の分離と同定法, 菜根出版, 東京.

17) Balch, W.E., Fox, G.E., Magrum, L.J., Woese, C.R. and Wolfe, R.S. (1979) Methanogens: Reevalution of unique biological group, Microbiological Reviews, 43, 260-296.

18）古賀洋介, 森井宏幸, 西原正照 (1987) メタン生成細菌の分 離・培養法の実際, 発酵工学, 65, 419-430.

19）李玉友, 足利伸行, 野池達也（1988）污泥の嫌気性消化にお けるメタン菌拉よびその活性の定量, 土木学会東北支部技術研 究発表会, 240-241.

20) Braun, M., Schoberth, S. and Gottschalk, G. (1979) Enumeration of bacteria forming acetate from $\mathrm{H}_{2}$ and $\mathrm{CO}_{2}$ in anaerobic habitats, Archives of microbiology, 120, 201-204.

21) Mackie, R.I. and Bryant, M.P. (1981) Metabolic activity of fatty acid oxidizing and the contribution of acetate, propionate, butyrate, and $\mathrm{CO}_{2}$ to methanogenesis in cattle waste at 40 and $60^{\circ} \mathrm{C}$, Applied and Environmental Microbiology, 41, 1363-1373.

22）日本下水道協会（1974）下水道試験法.

23) Herbert, D., Phipps, P.J. and Strange, R.E. (1971) Chemical analysis of microbial cells, Academic Press, London and New York, 53, 210.

24）菅原潔, 副島正美（1982）蛋白質の定量法, 95-131, 学会出 版センター, 東高.

25) 日本生化学会編 (1974) 生化学実験講座 3, 脂質の化学, 7 -15 , 東京化学同人, 東京.

26）李玉友, 野池達也（1988）余剰污泥の嫌気性消化に対する前 熱処理の促進効果, 第25回下水道研究発表会講演集, 478-480, 日本下水道協会.

27) 王偉, 平岡正勝, 武田信生, 酒井伸一, 後藤茂, 岡島重伸 (1988) 嫌気性消化プロセスの前処理とする下水污泥の熱処理に関す る研究一污泥固形物の可溶化反応を中心として一, 衛生工学研 究論文集, 24, 41-51.

28) Zeikus, J.G. (1980) Microbial populations in digesters, Anaerobic digestion, Applied Science Publishers Ltd 1980 61-67.

29) Yoda, M., Kitagawa, M. and Miyaji, Y. (1987) Long term competition between sulfate-reducting and methaneproducing bacteria for acetate in anaerobic biofilm, Water Research, 21, 1547-1556.

30) 銭泽澍, 閔航編著（1986）沼気発酵微生物学，浙江科学技術 出版社, 中国杭州.

31) 王偉, 平岡正勝, 武田信生 (1985) 熱変性メタン発酵プロセ スに関する研究, 土木学会第 40 回年次学術講演会講演概要集第 2 部, 725-726. 


\section{余㮃活性污泥の嫌気性消化に及ぼす前熱処理と滞留時間の影響}

李 玉友* 野池 達也*

* 東北大学工学部土木工学科

〈水質污濁研究 Vol.12 No.2 （1989） pp.112～121〉

余剰活性污泥の嫌気性分解特性に及ぼす前熱処理の促進効果の解明掞よび TP/AD プロセスの最適化を図

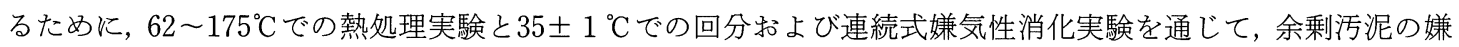
気的分解に及ぼす熱処理条件と消化時間の影響を検討した。その結果，以下のことが明らかとなった。1）熱 処理に伴ら污泥の可溶化, 低分子化执よ゙固形有機物の熱変性によって, 余剰活性污泥の嫌気的分解率と消化 ガス生成量が向上されただけでなく，消化時間も10日以下に短縮できる。2）嫌気性消化の効率化のための最

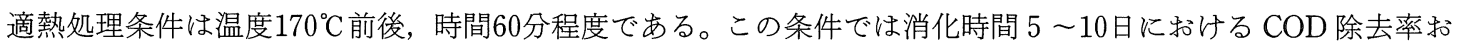

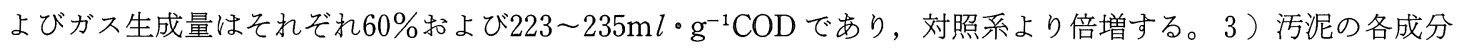
の分解に対する熱処理の促進効果は炭水化物＞たんぱく質〉脂質の順で大きい。4）滞留時間1.5〜10日の污 泥消化槽に扣けるメタン菌数は $10^{7} \sim 10^{8} \mathrm{No} \cdot \mathrm{m} l^{-1}$ である。

\section{制限曝気式回分活性污泥法による豚舎污水中の窒素の除去}

長田 隆* 羽賀 清典** 原田 靖生***

* 農林水産省畜産試験場飼養技術部環境整備第一研究室 ** 農林水産省農業環境技術研究所資材動態部 肥料動態科廃棄物利用研究室 $* * *$ 農林水産省農業環境技術研究所環境資源部土壌管理科土垬生化学研究 室

〈水質污濁研究 Vol.12 No.2 (1989） pp.122 130〉

制限曝気式回分活性污泥法による豚舎污水中の窒素・リンの除去について検討した。投入污水の水質は BOD : T-N : $\mathrm{PO}_{4}-\mathrm{P}=100 ： 33 ： 4$ であった。試験は BOD 容積負荷 0.25 执よび $0.50 \mathrm{~kg} \cdot \mathrm{m}^{-3} ・ \mathrm{~d}^{-1}$ にいて, 従来法である無制限曝気区 (NLAP)，污水投入後曝気を13時間和よび 8 時間制限する制限曝気区（LAP-13揖 よび LAP- 8 )の 3 つの区の処理効果を比較検討した。LAP の BOD と TOC の処理効果はNLAPと同様に良 好で，試験区間で差異はなかった。窒素の除去率は，BOD容積負荷 $0.50 \mathrm{~kg} \cdot \mathrm{m}^{-3} \cdot \mathrm{d}^{-1}$ の場合，NLAP が $19.2 \%$ であるのに対し LAP-13では $52.4 \%, L A P-8$ では53.9\%と高かった。1 日の処理過程に拈ける各種成分の変化 を経時的に測定した結果，LAP-13は幾分曝気不足と考えられる。また，窒素の除去率を向上させるためには， 硝酸化成を効率よく進行させることが必要と考えられる。 